\title{
HOLLYWOOD on the HUDSON
}





\section{HOLLYVIOOD on the HUDSON}

Film and Television in New York from Griffith to Samoff

\section{RICHARD KOSZARSKI}

19.

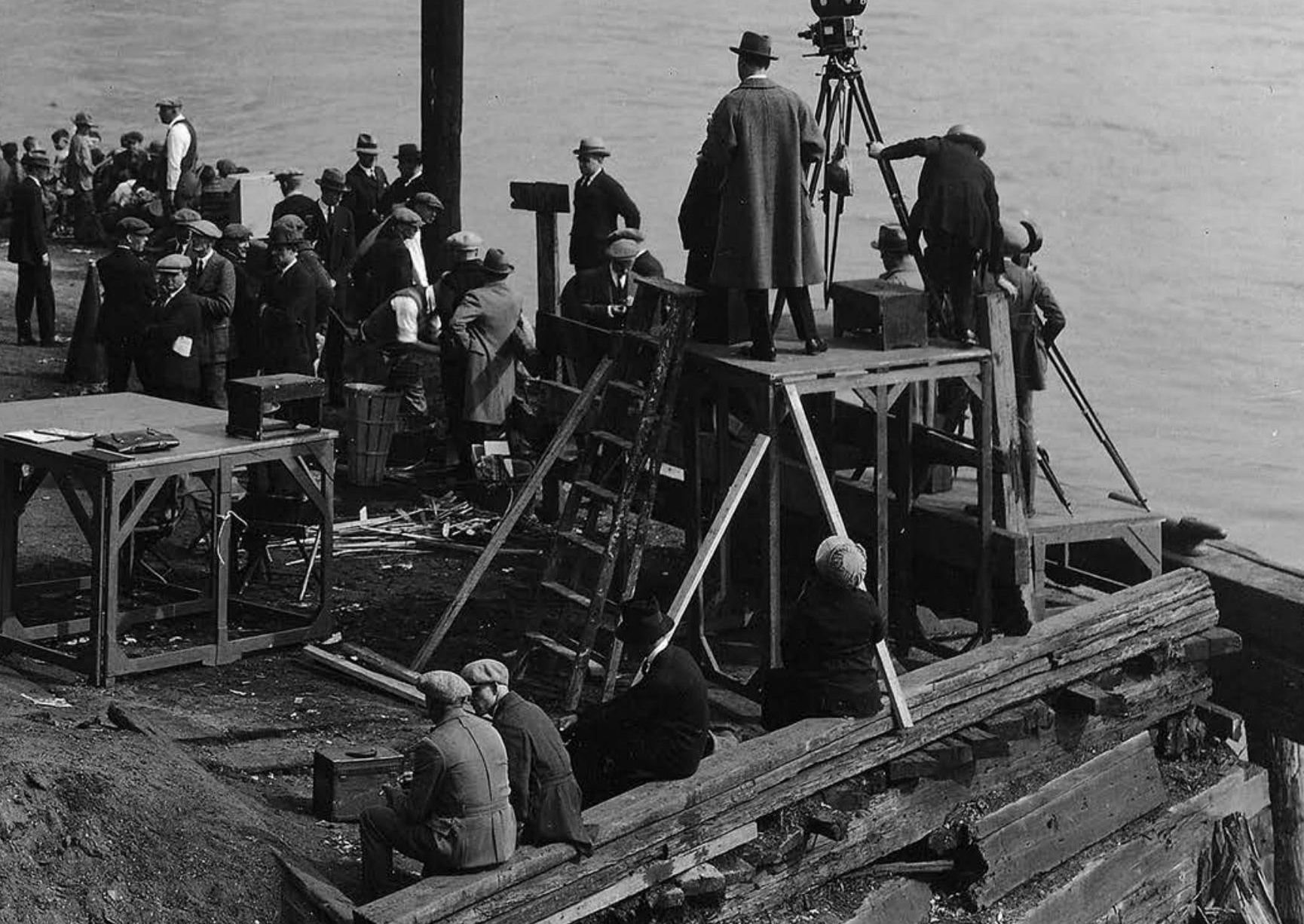


First paperback printing, 2010

Library of Congress Cataloging-in-Publication Data

Koszarski, Richard.

Hollywood on the Hudson : film and television in New York from Griffith to Sarnoff / Richard Koszarski.

p. $\mathrm{cm}$.

Includes bibliographical references and index.

ISBN-13: 978-0-8135-4293-5 (hardcover : alk. paper)

ISBN-13: 978-0-8135-4778-7 (pbk. : alk. paper)

1. Motion picture industry-New York (State)—New York—History. 2. Television broadcasting-

New York (State) —New York-History. I. Title.

PN1993.5.U77K67 2008

384.' 809747 dc22

2007029664

A British Cataloging-in-Publication record for this book is available from the British Library.

Copyright (C) 2008 by Richard Koszarski

All rights reserved

No part of this book may be reproduced or utilized in any form or by any means, electronic or mechanical, or by any information storage and retrieval system, without written permission from the publisher. Please contact Rutgers University Press, 100 Joyce Kilmer Avenue, Piscataway, NJ 08854-8099. The only exception to this prohibition is "fair use" as defined by U.S. copyright law.

Text design by Adam B. Bohannon

Visit our Web site: http://rutgerspress.rutgers.edu

Manufactured in the United States of America

Frontispiece: Big Brother (1923) filming on location in New York City. Bison Archives. 